\title{
The history of Arbovirology at Instituto Evandro Chagas, Belém, Pará, Brazil, from 1954 to 1998
}

\author{
A história da Arbovirologia no Instituto Evandro Chagas, Belém, Pará, Brasil, de 1954 \\ a 1998
}

Amelia Paes de Andrade Travassos da Rosa

University of Texas Medical Branch, Galveston, Texas, USA

\section{PREFACE}

THE ARBOVIROLOGY AND THE INSTITUTO EVANDRO CHAGAS

The history of Arbovirology at the Instituto Evandro Chagas (IEC) is a true love story of dedication and enthusiasm of a group of persons who gave so much of themselves to gather all the knowledge available on the arboviruses field in the Brazilian Amazon Region.

A significant and relevant part of studies conducted by this group included the antigenic characterization of new viral agents. This aspect has deep impact and fundamental importance in the recognition of new virus species. It allowed the world to learn about the existence of a large variety of distinct types of arbovirus and certain other viruses isolated from wild vertebrates and arthropods. In parallel, an extraordinary collection was established including more than 10,000 virus strains which have been using for experimental studies on the pathogenesis, ultra-structure, molecular biology, and evolution of these agents by future generations of scientists.

\section{GRATITUDE}

I started working at Belém Virus Laboratory, Pará State, Brazil in January 1959 (Figure 1), and was happy and felt grateful for the great opportunity to begin my professional life under the mentoring of a distinguished human being of unquestionable intelligence and extremely honest, kind and simple: Dr. Robert E. Shope. In the close association for more than 40 years, I was honored to receive from him lessons of science and life.

\section{BACKGROUND}

Drs. Ottis and Calixta Causey (Figure 2), researchers of the Rockefeller Foundation (RF), were the first directors of the Belém Virus Laboratory, and had the collaboration of IEC scientists Otávio Maroja and

\section{Correspondence / Correspondência:}

Amelia Paes de Andrade Travassos da Rosa

University of Texas Medical Branch, Galveston, TX 77555, USA

E-mail:aptravas@utmb.edu
Dulcimar Macedo. Later, Drs. Robert E. Shope, John P. Woodall, Jorge Boshell and Thomas Aitken, from the RF, were also recruited to Belém.

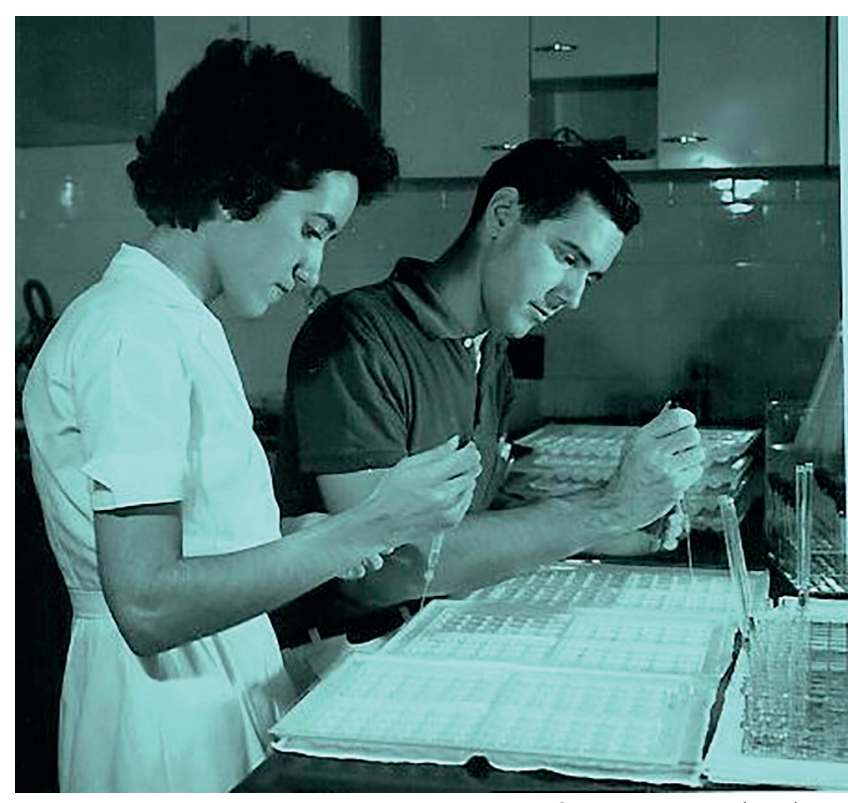

Figure 1 - Dr. Robert Shope and Amelia P. A. Travassos da Rosa conducting the complement fixation (CF) test in their laboratory facility at the Belém Virus Laboratory, 1959

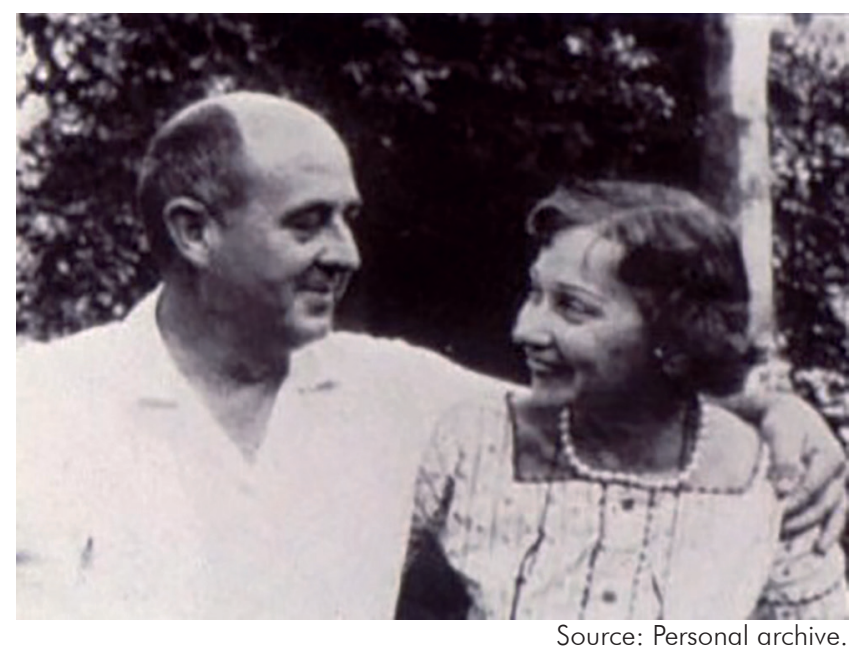

Figure 2 - Drs. Ottis and Calixta Causey, first directors of the Belém Virus Laboratory 
At the same time, a new technical Brazilian team including Francisco P. Pinheiro, Amelia P. A. Travassos da Rosa, Gilberta Bensabath and Amazonia Toda began to participate in the program. In 1970, with the end of the financial support provided by RF, the newly denominated Section of Arbovirus (Seção de Arbovirologia e Febres Hemorrágicas - SAARB nawadays) was directed by Dr. Francisco P. Pinheiro and received support from Pan American Health Organization (PAHO) until 1975. With the departure of Dr. Pinheiro to Washington in 1979, I assumed the direction of the SAARB until 1998 when I retired, thus finishing the pioneering days of the Causeys or "old generation of Arbovirologists". During that period, a group was composed including researchers and technicians who worked with competence, professionalism and dedication for all that time, and I was also grateful to them.

In 1999, the direction of SAARB was assumed by Dr. Pedro Fernando da Costa Vasconcelos, beginning the second phase, or "new generation of the Arbovirologists".
But I am going to write just about one chapter of these years of our remarkable trajectory between 1980 and 1998. Much has been written about the early years by other contemporary researchers ${ }^{1,2,3,4}$, and certainly much more will be written by our successors.

\section{BELÉM ARBOVIRUS LABORATORY STAFF: 1980-1998}

It was a very important period in the Arbovirology history, not only in Pará State, however to the world. I wish to express my acknowledgements to colleagues of the Arbovirus group, such as Pedro Fernando da Costa Vasconcelos, Jorge Fernando Soares Travassos da Rosa, Jean Pierre Herve, Nicolas Degallier, Bernard Mondet, Sueli Guerreiro Rodrigues, Elizabeth Salbé Travassos da Rosa, Ana Cecília Ribeiro Cruz, and Ronaldo Freitas for their crucial effort and dedication in the development that allowed us to reach our goals. The laboratory environment was not only productive, but also friendly, and was constitute for researchers and technicians that, in general, were respectful and very dedicated to their works (Figure 3).
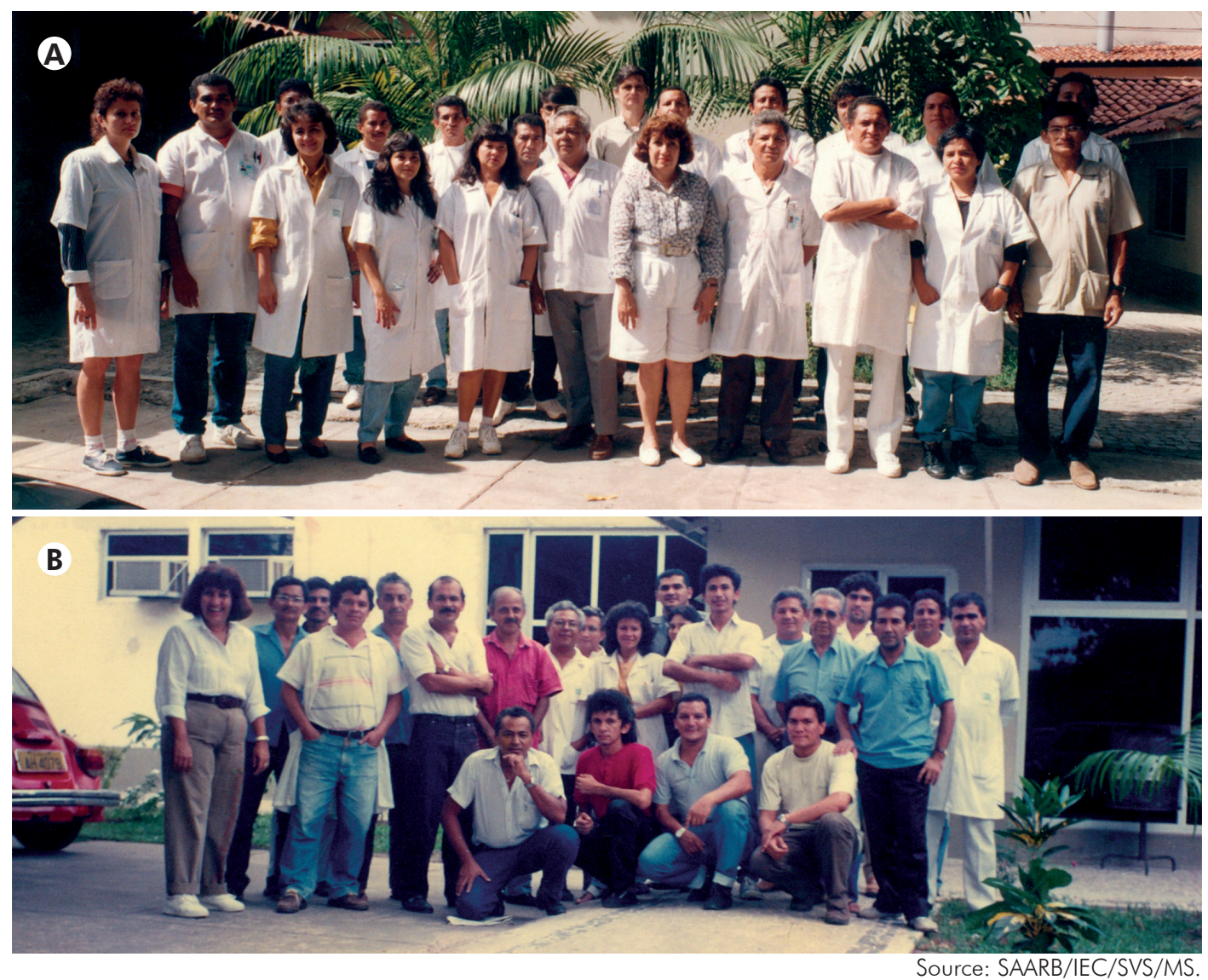

The group of researchers and technicians identified:

A: Behind, from left to right - Olinda Macedo, Armando de Souza Pereira, Raimundo Macedo dos Reis, Basílio Silva Buna, Jonas Raimundo dos Santos Moraes, Nicholas Degallier, Francisco Correa Castro, Hamilton Antônio Oliveira Monteiro, Iveraldo Ferreira da Silva, Hélio Augusto Cardoso Saraiva, Luis Roberto Oliveira da Costa. In front, from left to right - Elizabeth Salbé Travassos da Rosa, Sueli Guerreiro Rodrigues, Maria Rute Castro de Freitas, Osvaldo Vaz da Silva, Amelia P. A. Travassos da Rosa, Orlando Vaz da Silva, Pedro Fernando da Costa Vasconcelos, Ana Cecília Ribeiro Cruz, Enéas Francisco da Silva.

B: Seated, from left to right - João Brandão, Marcos Muller, Francisco Correa Castro, Hélio Augusto Cardoso Saraiva. Standing, from left to right - Amelia P. A. Travassos da Rosa, Enéas Francisco da Silva, Basílio Silva Buna, Antônio Silva Santos, Raimundo Pereira da Silva, unknown, Raimundo Benedito da Silva, Osvaldo Vaz da Silva, Raimundo Farias do Nascimento, Norma Sueli, Maria Rute Castro de Freitas, Armando Pereira de Souza, Roberto Carlos Feitosa Brandão, Orlando Vaz da Silva, Raimundo Rodrigues Pinheiro, Iveraldo Ferreira da Silva, Jonas Raimundo dos Santos Moraes, Hamilton Antônio Oliveira Monteiro, Ronaldo Freitas.

Figure 3 - Belém Arbovirus Laboratory staff, 1980-1998 
This period was very productive, many research activities were carried out in order to study arbovirus outbreaks in different Brazilian States:

- Hundreds of arboviruses were antigenically characterized, comprising 94 distinct serological types (Figure 4).

- Many important research projects were developed in collaboration with national and international organizations.

- More than 200 papers were presented in scientific meetings, as well as published in national and international journals in the virology field.

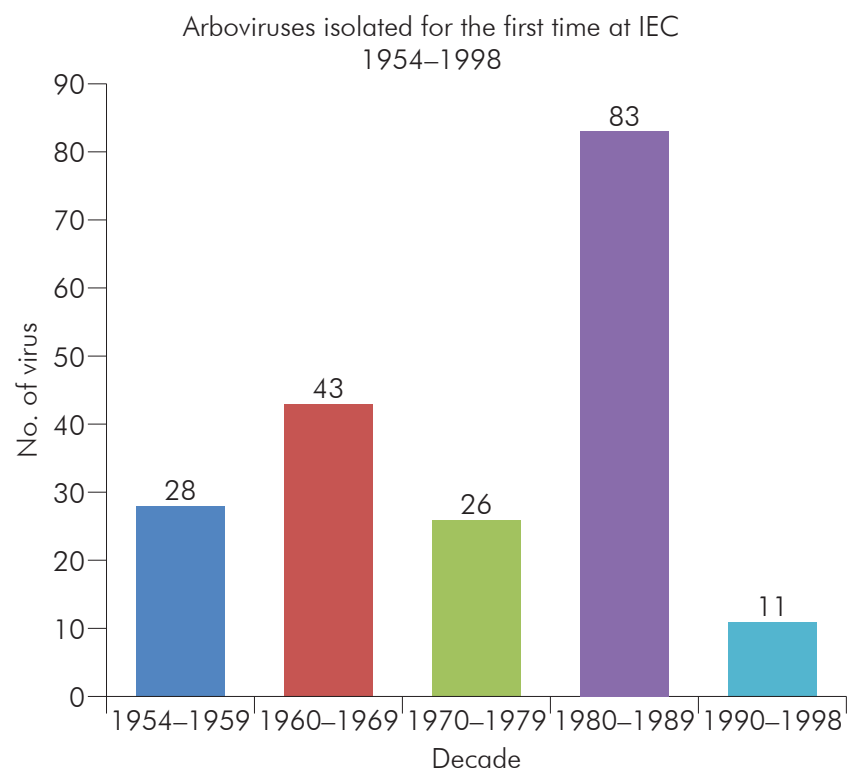

Figure 4 - Number of virus isolates obtained by decade during eco-epidemiological studies conducted by SAARB/ IEC between 1954 and 1998

\section{RESEARCH PROJECTS}

Along all that period, SAARB conducted many research projects in the Amazon Region investigating eco-epidemiological aspects of the arboviruses and the impact of anthropic action in this complex ecosystem. At the same period, the Tucuruí hydroelectric dam was built, and several other human actions in the forest that led to the emerging of several viruses and contributed substantially to a better understanding about the vast arbovirus, zoonotic viruses and other certain viruses biodiversity in the Amazon, a challenge for several future generations of arbovirologists.

\section{2-1987: ARBOVIRUSES IN SERRA NORTE, CARAJÁS REGION, PARÁ, BRAZIL}

Carajás mine is one of the largest mines in the world for iron extraction and is placed in Serra Norte area, Municipality of Parauapebas, Pará State, northern Brazil. During the project period, a total of 184,884 haematophagous insects were collected, blood and tissue samples were obtained from 1,726 wild vertebrates caught in that area. Attempts to isolate viruses in suckling mice yielded 21 strains, including 15 different serological types, of which seven have been shown to constitute new types, so far found only in the Brazilian Amazon Region. Furthermore, two of them have already been confirmed to be new types to the world. Serological studies performed on 2,680 sera $(1,380$ wild humans and 1,300 wild animals) against selected arboviruses pointed out the circulation of several of these agents in the investigated area $^{5}$.

\section{3-1989: CONSTRUCTION OF THE TUCURUÍ HYDROELECTRIC DAM IN PARÁ}

The hydroelectric dam facilities was built in the 1980's in the Tucuruí area, on the Tocantins river, Pará State, northern Brazil, and a site of development of important industrial complex in the large region which surrounds the areas of Serra Norte and Serra Sul, as well as the domain along Carajás railway, in the Municipality of Marabá, Pará State. During the construction, large areas of tropical forest were flooded (Figure 5).
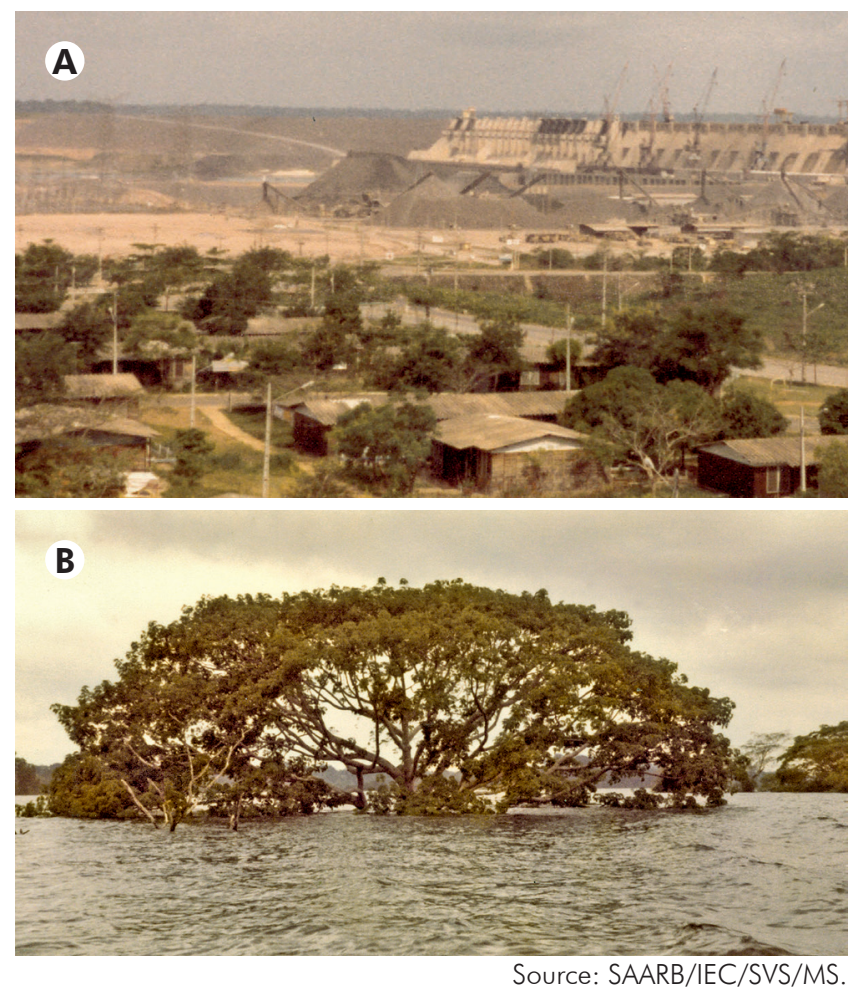

Figure 5 - Panoramic view of the Tucuruí hydroelectric dam (A) and the devastating flooding provided by the Tucuruí river containment by the enormous dam walls (B)

A total of $1,263,454$ mosquitoes and phlebotomine sandflies were captured. A large number (216) of viruses were isolated from these arthropods, including 37 new types to Brazil and probably four new ones to science $^{6,7}$.

\section{1-1999: THE ECOLOGY OF YELLOW FEVER VIRUS AND OTHER ARBOVIRUSES}

In 1977, Dr. Francisco Pinheiro (Director of the IEC), and Dr. Jean Mouchet (President of the Technical Committee of Medical Entomology at IRD, Paris, France) began to develop a plan for collaborative work between the two countries. Three medical entomologists were in Belém: Jean Pierre Herve (1981-1983), 
Nicolas Degallier (1983-1985) and Bernard Mondet (1994-1999).

There were 58 publications, including:

- Ecological aspects of arboviruses in Brazilian Amazon.

- Impact of hydroelectric dam construction and mineral exploration on arboviruses transmission.

- Bioecology of Haemagogus janthinomys and Sabethes spp., vectors of yellow fever.

- Studies on fauna and taxonomy of Culicidae.

1988: BALBINA HYDROELECTRIC DAM IN AMAZONAS STATE

In 1988, studies were conducted in Balbina hydroelectric dam, Uatuma river, Municipality of Presidente Figueiredo, Amazonas State. In this occasion, two new viruses (Changuinola group, genus Orbivirus, family Reoviridae) were isolated from phlebotomines collected in Balbina.
1995: ECO-EPIDEMIOLOGIC STUDIES IN SELECTED AREAS

Brazilian Army, Military Command in the Amazon: Training Center and war procedures in the forest (Centro de Instrução de Guerra na Selva)

The SAARB has been established several cooperative works for arbovirus eco-epidemiological studies, including those in Rio Preto da Eva, located $60 \mathrm{~km}$ far from Manaus City, Amazonas State, northern Brazil. The Brazilian Army base, where the studies were carried out, is located between km 52 and 72 along Manaus-Itacoatiara (AM-174) highway (Figure 6). Two field trips were made in the area in order to capture blood suckling insects and detect arbovirus circulation. Two arboviruses strains were obtained: one identified as Tacaiuma virus (genus Orthobunyavirus, family Bunyaviridae) isolated from Haemagogus janthinomys; and Rio Preto da Eva virus was isolated from a pool of Psychodidae sp. (Diptera: Phlebotominae) and identified as distinct virus within the family Bunyaviridae.
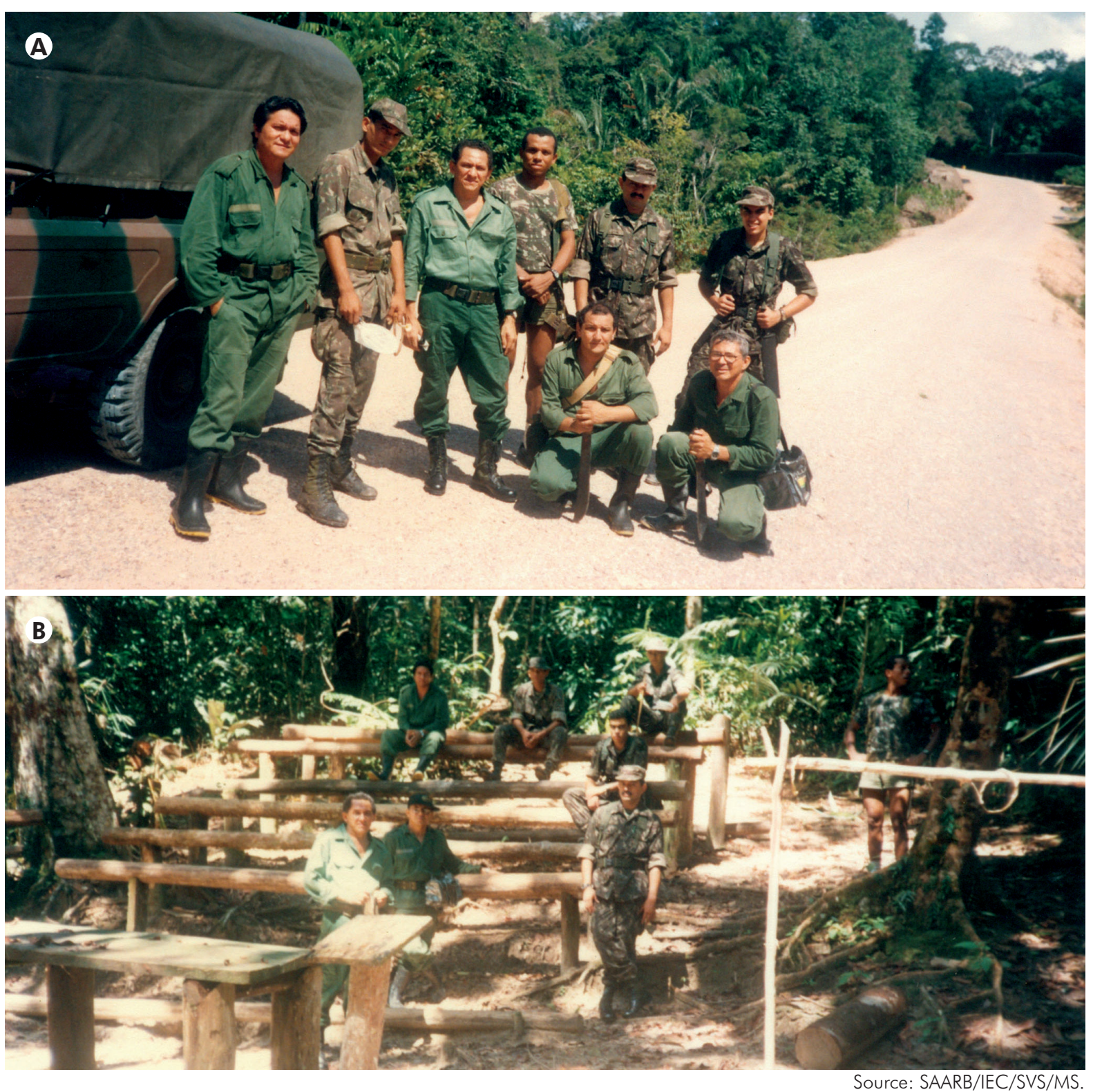

A: SAARB and Brazilian Army staffs; B: Brazilian Army training site.

Figure 6 - SAARB and Brazilian Army staffs in a classical memory picture in the Manaus-Itacoatiara unpaved highway 


\section{Instituto de Pesquisa Experimental do Amapá (IPEA)}

Zoobotanical Park of Macapá, Amapá State (August 18 to September 11, 1995)

The collections were done at both ground and canopylevels in the forest and at ground level in the savannah, with human bait and light traps. 5,642 mosquitoes have been collected, of which 5,580 (or 184 pools) have been inoculated intracerebrally in newborn mice. Two strains of Pacoravirus (PACV) have been isolated from unidentified Culex mosquitoes. This result is the first report of PACV in Amapá State. The virus has also been isolated for the first time from mosquitoes in $\mathrm{Brazil}^{8}$.

Laranjal do Jari, Amapá State (September 22-29, 1995)

During this period, 747 blood suckling dipterans identified as members of the Ceratopogonidae $(200=2$ pools $)$ and Psychodidae $(245=45$ pools) families were captured. These materials, after inoculation in newborn baby mice, provided the isolation of two strains: one from phlebotomines, and another from Aedes serratus mosquitoes. The viruses were identified by CF test as members of the Changuinola group (Orbivirus, Reoviridae), and Aura (A group, Alphavirus, Togaviridae), respectively.

\section{COLLABORATIONS}

The success of our laboratory has been supported by a national and an international network, which has provided important collaborations in many different projects along our remarkable trajectory on arbovirus research.

Regional Collaborators: Universidade Federal do Pará, Hospital Universitário João de Barros Barreto, Museu Paraense Emílio Goeldi, Fundação de Medicina Tropical do Amazonas.
National Collaborators: Fundação Nacional de Saúde (Funasa), Conselho Nacional de Desenvolvimento Científico e Tecnológico (CNPq), Faculdade de Saúde Pública (Universidade de São Paulo), Fundação Oswaldo Cruz, Instituto Adolfo Lutz.

International Collaborators: Rockefeller Foundation, Yale Arbovirus Research Unit, Walter Reed Army Unit, Centers for Disease Control and Prevention, BernhardNocht Institute for Tropical Medicine, Institut de Recherche pour le Développement, University of Texas Medical Branch.

\section{CREDENTIALS}

In recognition to the work in excellence on arbovirus research, important credentials were honored to SAARB during that period by the World Health Organization and the Brazilian Ministry of Health:

\section{World Health Organization}

1983: The World Health Organization designated the IEC as a Collaborating Center for Arbovirus Reference and Research.

\section{The Brazilian Ministry of Health}

1988: The Brazilian Ministry of Health, by edict, indicated the IEC as a National Reference Laboratory on Arbovirus Research.

\section{SCIENTIFIC EVENTS AND PROFICIENCY TESTS}

Scientific events and proficiency tests were prepared and hosted by the IEC. Here I am referring the remarkable ones as follow:

\section{International Symposium on Tropical Arboviruses and Haemorrhagic Fevers (April 14-18, 1980)}

Milestone celebrated the $25^{\text {th }}$ anniversary of the scientific activities on arbovirus research that carried out in the Amazon Region providing an updated view regarding the panorama of the arboviruses and hemorrhagic fevers (Figure 7).

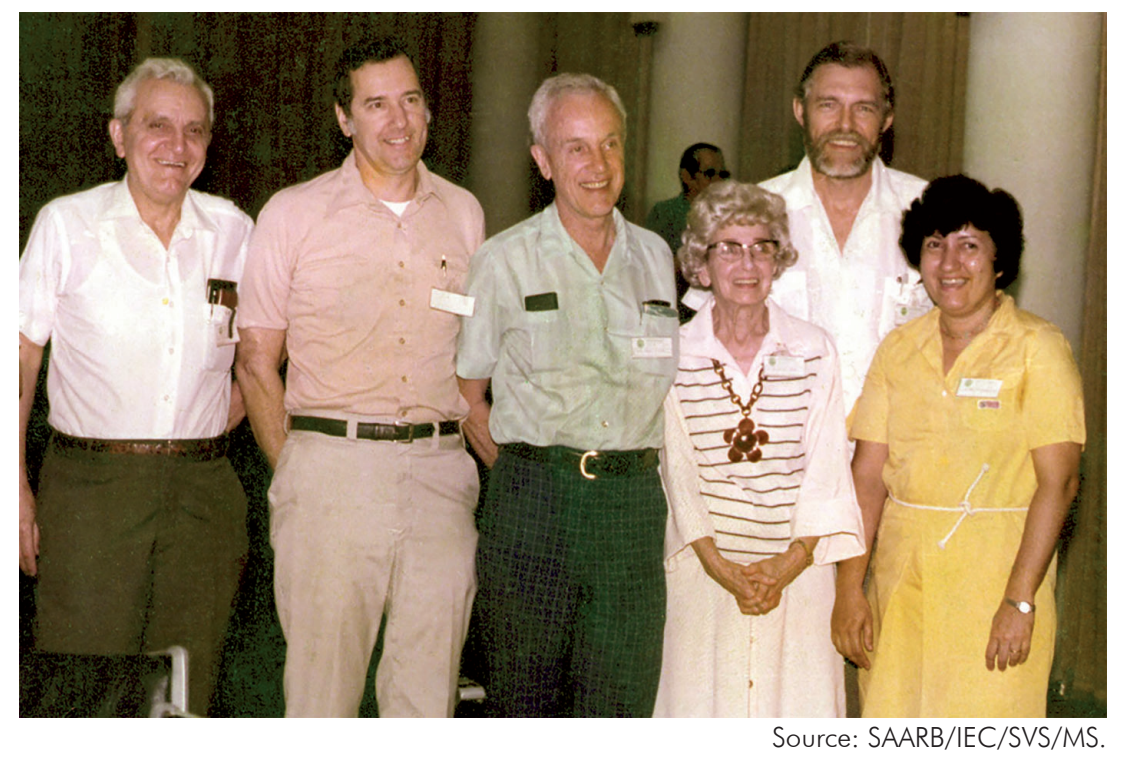

Figure 7 - From left to right Drs. Casals, Shope, Aitken, Causey, Woodall and Amelia at the International Symposium on Tropical Arboviruses and Haemorrhagic Fevers, 1980 


\section{International workshop on laboratory diagnosis of Yellow fever and Dengue virus infections (1990)}

Participation of 34 researchers and technicians with experience in Virology/Pathology, from several countries of South America and also from the United States. The importance of this event was the improvement of the diagnosis of these diseases in Brazil.

\section{Proficiency test for dengue diagnosis (1995)}

Enrolling 11 different laboratories in the States of Ceará, Pernambuco, Bahia, Minas Gerais (Fundação Ezequiel Dias), Goiás, Mato Grosso, Mato Grosso do Sul, Distrito Federal, Rio de Janeiro, and Paraná.

\section{Book edition: An Overview of Arbovirology in Brazil and Neighbouring Countries (1998)}

This book was organized in three sections, each one focusing on different aspects of arboviruses with 47 collaborators in South America, USA, and France?

\section{ARBOVIRUSES PATHOGENIC FOR HUMANS}

Thirty six arboviruses and other viruses of vertebrates have been associated with human disease among over 200 isolates made in Brazil; five of them are important in public health and are involved in epidemics. They are: Dengue (DENV) complex, Mayaro (MAYV), Oropouche (OROV), Rocio (ROCV), and Yellow fever (YFV) viruses.

OROV and DENV are associated with epidemics of human disease in urban areas, while MAYV, ROCV, and YFV have been responsible for epidemics in rural areas. A special attention should be direct to DENV, due to the fact that this virus has been isolated by the first time in Brazil in 1982 in the City of Boa Vista, Roraima State, and has caused subsequently outbreaks in Pará from 1995 to 1998.

DENGUE IN RORAIMA STATE: THE FIRST CLINICAL AND LABORATORIAL REPORTED DENGUE VIRUS (DENV) OUTBREAK IN BRAZIL

-1982: The first laboratory confirmed cases of Dengue fever in Brazil - virus isolation and serological results in Boa Vista.

- That time, 12 isolations of DENV were made from human samples: eight strains of DENV-1 and four of DENV-4. All infections were confirmed testing the sera by $\mathrm{HI}$ test. All results revealed serological conversion.

- Two isolates of DENV-4 and one of DENV-1 were made from Aedes aegypti mosquito's pools.

- Fourteen serological conversions without virus isolation.

- High rates of flavivirus $\mathrm{HI}$ antibodies in several districts of Boa Vista, especially in downtown area, where large numbers of Ae. aegypti were found.

- During the outbreak, 11,000 persons were estimated to be infected by DENV10,11.

\section{DENGUE IN PARÁ STATE}

Following the first outbreak in Roraima, an impressive outbreak of DENV was experienced in Pará State where the virus was first detected in the Municipalities of Redenção and Rondon do Pará, and spread to other urban areas such as Belém (Capital of Pará State) and metropolitan region. Below are some milestones for the DENV outbreak in Pará State:

-1995: First autochthonous cases of dengue in Redenção and Rondon do Pará.

- From 1996 to 1998: Dengue epidemic in Belém and Ananindeua.

During 1997, an explosive dengue epidemic was occurred in Belém and Ananindeua, Municipalities that composed the metropolitan area of Belém, Pará State. Transmission began in October of 1996, but crawled in a lag phase period for almost four months. The epidemic situation was established with transmission starting from March, as consequence of the rainy season in Belém during the first months of the year. Initially, transmission was limited to Belém and Ananindeua, but with passage of the time, other Municipalities also reported autochthonous transmission. The implicated serotype was DENV-1. In October of 1997, DENV-2 serotype was isolated; both serotypes have coexisted since that time.

The transmission was made by the mosquito Ae. aegypti and 799 virus isolations were obtained from blood. Of the isolated samples, 751 were of DEN-1 and 48 of DEN-2. From 16,760 lgM positive cases, 3,277 patients had serologic conversion. The distribution per sex was not statistically significant $(p>0.05)$.

During 1998, studies remained about dengue epidemic in Belém and Ananindeua. The Laboratory continued to support epidemiological surveillance of other States, by means of serologic and virologic studies that allowed the accomplishment of 787 cultures and 13,303 tests of IgM capture immunoassay (MAC ELISA). As consequence, 124 strains of the dengue virus were isolated, and 5,377 recent infections were diagnosed by the detection of IgM using MAC ELISA. The serotypes that circulated varied from one State to another, but they continue being DEN-1 and/or DEN-2.

Dengue epidemics continues to spread in Brazil with outbreaks in the States of Alagoas (in June 1986) and Ceará (September 1986) 12. A large epidemic of dengue fever associated to dengue haemorrhagic cases were reported in Ceará in 1994 and was considered a great problem to the health authorities ${ }^{13}$.

\section{MAYARO VIRUS}

In Brazil, the virus is endemic to the Amazon Region, where at least four epidemics have been reported in Pará in a community of quarry workers 
on Guamá river in 1955; Belterra, a rural village of rubber plantations, in 1978; Conceição do Araguaia in 1981, and Benevides in 1991. Outside Pará, two other outbreaks were registered in Itaruma, Goiás State in 1987, and in Peixe, Tocantins State in 1991. Specific antibodies against MAYV were also found in Xavante indians of Mato Grosso State, and in inhabitants from rural areas of Goiás State in Central Brazil. Although high antibodies rates are found in some rural communities of the Amazon basin of Brazil'1, it is difficult to isolate MAYV, because of the relatively short period of viremia ${ }^{14,15}$ (Figure 8).

\section{OROPOUCHE VIRUS}

OROV was first isolated in Brazil from the blood of a slot (Bradypus trydactilus) captured nearby the Belém-Brasilia highway, and since that until 1980, OROV caused several outbreaks reported in Pará, Northern Brazil, reaching different municipalities and distinct mesoregions: Metropolitan Region of Belém (Municipalities of Belém, Ananindeua, Benfica, Carapary, Castanhal and Santa Isabel); Northeast (Abaetetuba, Augusto Corrêa, Baião, Bragança, Capanema, Curuçá, Tomé-Açu, Vigia and Viseu); Southeast (Itupiranga); Lower Amazon (Belterra, Mojuí dos Campos and Santarém); and Marajó island (Porto de Moz). During this period, there were no reported cases of Oropouche fever in the southwest mesoregion ${ }^{16,17,18,19,20,21}$.

Between 1981 and 1996, outbreaks of Oropouche fever were registered in the Municipalities of Oriximiná, Brazil Novo and Altamira, Pará State. Cases of Oropouche fever were also reported outside Pará, in the States of: Amazonas - Manaus, Novo Airão and Barcelos; Amapá - Mazagão; Acre - Xapuri; Rondônia - Ariquemes, Machadinho and Ouro Preto d'Oeste; Maranhão - Porto Franco and Estreito; and Tocantins Tocantinópolis. Outbreaks outside the country were also reported in Panama, in 1989, and in Peru from 1992 to 1998 (lquitos), and in Puerto Maldonado in 1993 (Figure 9) 9,19,21,22.

\section{YELLOW FEVER VIRUS}

Epizootics of yellow fever have been periodically reported in Brazil mainly in the 1930-40s and between 1998 and 200923. In the Amazon Region and other endemic regions, epizootic outbreaks have been reported and associated to a sylvatic cycle involving non-human primates and mainly the Haemagogus and Sabethes mosquitoes. Until 1998, the most expressive epizootic outbreaks occurred in Goiás State (Central-Western Region) between 1972 and 1988, as well as in Maranhão in 1993-1994 and Pará in 1998-199924,25.

\section{INSTITUTIONAL SCIENTIFIC INITIATION SCHOLARSHIP PROGRAM}

The Institutional Scientific Initiation Scholarship Program (Programa Institucional de Bolsas de Iniciação Científica - PIBIC) is a National Counsel of Technological and Scientific Development (CNPq) program aimed at educating new researchers by including young talents in research projects, under guidance of researchers. During this period, some students received the scholarships and composed the first group from the $\mathrm{PIBIC/CNPq}$ class of the program established in the IEC.

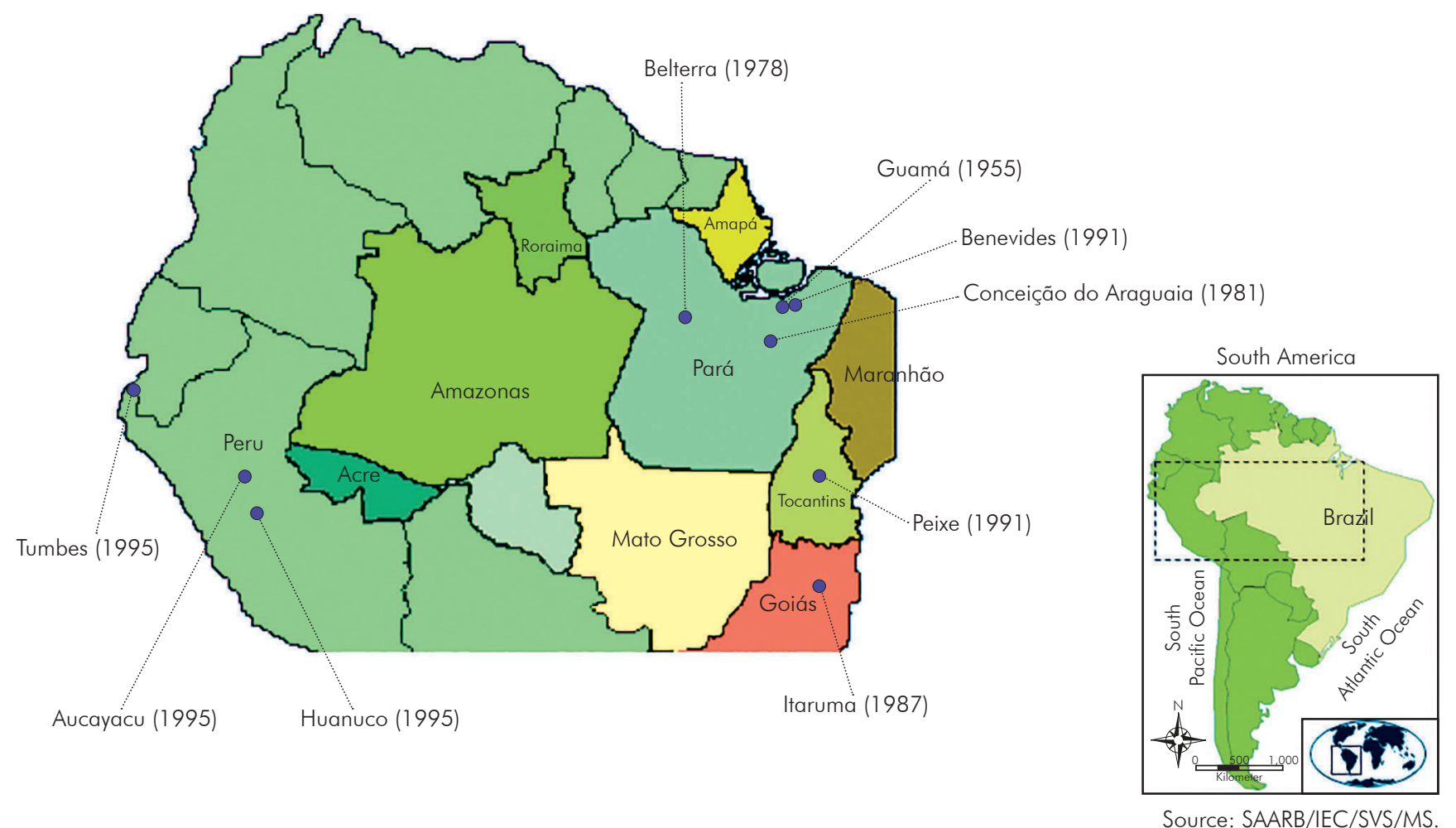

Figure 8 - Geographic distribution of MAYV outbreaks in Brazil (1955 to 1991) and Peru in 1995 


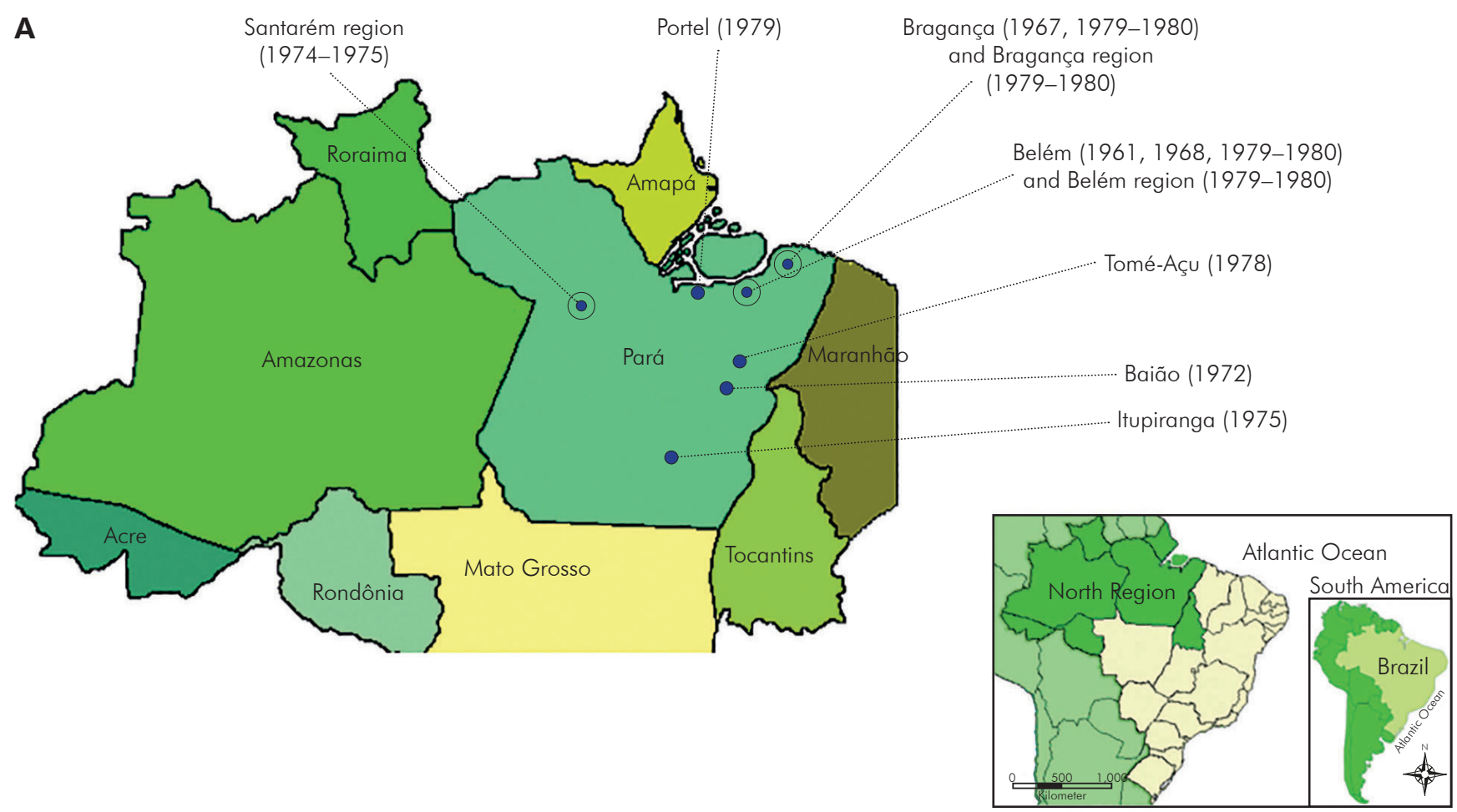

B

Novo Airão (1996)

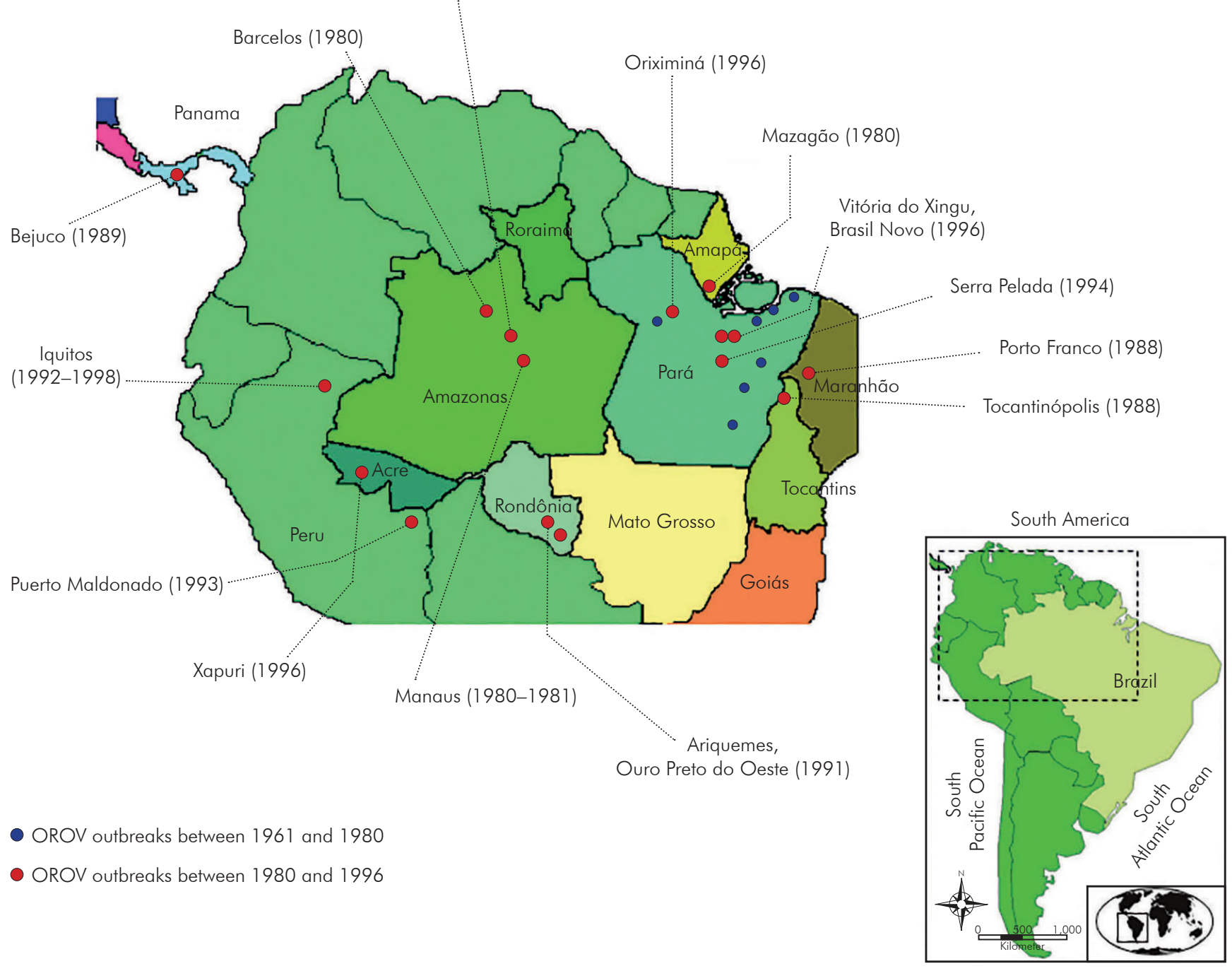

Source: SAARB/IEC/SVS/MS.

A: OROV outbreaks reported in Brazil; B: Outbreaks reported in Brazil, Panama and Peru.

Figure 9 - Geographical dispersal of OROV outbreaks reported in Brazil between 1961 and 1980, and in Brazil, Panama and Peru between 1980 and 1996 


\section{CONCLUSION}

In summary, the period of 44 years (1954-1998) was extremely productive providing 191 different viruses and more than 10,000 virus isolates. Notably, the majority of the virus isolations were reported in the 1980 's with a total of 83 distinct viruses. This great number of isolations coincided with the construction of the Tucuruí hydroelectric dam demonstrating the important impact in the environment and the influence of the anthropic actions to the emergence of viral agents. This is a result of an intense, dedicated, and remarkable work in the field of arbovirology in Brazil.

\section{AKNOWLEDGEMENTS}

To Dr. Márcio Roberto Teixeira Nunes and Dawn Auguste for their assistance in this report.

\section{REFERENCES}

1 Causey CE, Causey OR. Development of arbovirus studies in the Amazon region. In: Simpósio Internacional sobre Arbovírus dos Trópicos e Febres Hemorrágicas; 1980 Apr 14-18; Belém, Brasil. São Paulo: Conselho Nacional de Desenvolvimento Científico e Tecnológico; 1982. p. 13-20.

2 Shope RE. A history of Arbovirology in Brazil: Belém, PA 1954-1965. In: Travassos da Rosa APA, Vasconcelos PFC, Travassos da Rosa JFS, editors. An overview of Arbovirology in Brazil and neighbouring countries. Belém: Instituto Evandro Chagas; 1998. p. 11-7.

3 Woodall JP. Virus research in Amazônia. In: Lent H, editor. Atas do Simpósio sôbre a Biota Amazônica; 1966 jun 6-11; Belém, Brasil. Rio de Janeiro (RJ): Conselho Nacional de Pesquisas; 1967. p. 31-63. (Patologia; v. 6).

4 Pinheiro FP. Situação das arboviroses na Região Amazônica. In: Simpósio Internacional sobre Arbovírus dos Trópicos e Febres Hemorrágicas; 1980 abr 14-8; Belém, Brasil. São Paulo: Conselho Nacional de Desenvolvimento Científico e Tecnológico; 1982. p. 27-48.

5 Travassos da Rosa APA, Travassos da Rosa JFS, Herve JP, Vasconcelos PFC, Dégallier N, Rodrigues SG. Arboviruses in Serra Norte, Carajás Region, Pará, Brazil. Cienc Cult. 1992 Mar-Jun;44(2/3):158-61.

6 Dégallier N, Travassos da Rosa APA, Hervé JP, Vasconcelos PFC, Travassos da Rosa JFS, Sá Filho GC, et al. Modifications of arbovirus eco-epidemiology in Tucurui, Para, Brazilian Amazonia, related to the construction of a hydroelectric dam. In: Uren MF, Blok J, Manderson, $\mathrm{LH}$, editors. Arbovirus Research in AustraliaProceedings Fifth Symposium. 1989 Aug 28-Sep 1; Brisbane, Australia. Brisbane: Queensland Institute of Medical Research; 1989. p. 124-35.

7 Dégallier N, Travassos da Rosa APA, Vasconcelos PFC, Hervé JP, Sá Filho GC, Travassos da Rosa JFS, et al. Modifications of arbovirus transmission in relation to construction of dams in Brazilian Amazonia. Cienc Cult. 1992 Mar-Jun;44(2/3):124-35.
8 Souto RNP, Degallier N, Travassos da Rosa APA, Travassos da Rosa JFS. Occurrence of Pacora virus (PAC: Bunyaviridae: Bunyavirus-like) in Brazilian Amazonia: new findings. Cienc Cult. 1996 Jul-Aug;48(4):261-63.

9 Travassos da Rosa JFS, Travassos da Rosa APA, Vasconcelos PFC, Pinheiro FP, Rodrigues SG, Travassos da Rosa ES, et al. Arboviruses isolated in the Evandro Chagas Institute, including some described for the first time in the Brazilian Amazon region, their known hosts, and their pathology for man. In: Travassos da Rosa APA, Vasconcelos PFC, Travassos da Rosa JFS, editors. An overview of Arbovirology in Brazil and neighboring countries. Belém: Instituto Evandro Chagas; 1998. p. 19-31.

10 Osanai CH, Travassos da Rosa APA, Tang AT, Amaral RS, Passos ADC, Tauil PL. Surto de dengue em Boa Vista, Roraima: nota prévia. Rev Inst Med Trop S Paulo. 1983 jan-fev;25(1):53-4.

11 Travassos da Rosa APA, Nakauth C, Salaun JJ, Travassos da Rosa JFS, Hervé JP. Surto de dengue em Boa Vista, Roraima. Bol Epidemiol. 1982;14(9):93-100.

12 Figueiredo LTM. Dengue in Brazil: past, present and future perspective. Dengue Bull. 2003 Dec;27:25-33.

13 Vasconcelos PFC, Menezes DB, Melo LP, Paula Pessoa ETF, Rodrigues SG, Travassos da Rosa $E S$, et al. A large epidemic of dengue fever with dengue hemorrhagic cases in Ceará State, Brazil, 1994. Rev Inst Med Trop S Paulo. 1995 May-Jun;37(3):253-5.

14 Coimbra TLM, Santos CLS, Suzuki A, Petrella SMC, Bisordi I, Nagamori AH, et al. Mayaro virus: imported cases of human infection in São Paulo State, Brazil. Rev Inst Med Trop S Paulo. 2007 Jul-Aug;49(4):221-4.

15 Pinheiro FP, Travassos da Rosa APA, Freitas RB. Arboviroses: aspectos clínico-epidemiológicos. In: Ministério da Saúde (BR). Fundação Serviços de Saúde Pública. Instituto Evandro Chagas: 50 anos de contribuição às ciências biológicas e à medicina tropical. Vol. 1. Belém: FSESP; 1986. p. $375-408$. 
16 Vasconcelos PFC, Travassos da Rosa JFS, Guerreiro SC, Dégallier N, Travassos da Rosa ES, Travassos da Rosa APA. Primeiro registro de epidemias causadas pelo vírus Oropouche nos Estados do Maranhão e Goiás, Brasil. Rev Inst Med Trop S Paulo. 1989 jul-ago;31 (4):271-8.

17 Rosa APAT, Rodrigues SG, Nunes MRT, Magalhães MTF, Rosa JFST, Vasconcelos PFC. Epidemia de febre do Oropouche em Serra Pelada, município de Curionópolis, Pará, 1994. Rev Soc Bras Med Trop. 1996 nov-dez;29(6):537-41.

18 Freitas RB, Pinheiro FP, Santos MAV, Travassos da Rosa APA, Travassos da Rosa JFS, Freitas EN. Epidemia de vírus Oropouche no leste do Pará. In: Simpósio Internacional sobre Arbovírus dos Trópicos e Febres Hemorrágicas; 1980 abr 14-18; Belém, Brasil. São Paulo: Conselho Nacional de Desenvolvimento Científico e Tecnológico; 1982. p. 419-39.

19 Le Duc JW, Pinheiro FP. Oropouche fever. In: Monath TP, editor. The arboviruses: epidemiology and ecology. Vol. 4. Boca Raton: CRC Press; 1988. p. 1-14.

20 Pinheiro FP, Travassos da Rosa APA, Travassos da Rosa JFS, Ishak R, Freitas RB, Gomes MLC, et al. Oropouche virus. I. A review of clinical, epidemiological, and ecological findings. Am J Trop Med Hyg. 1981 Jan;30(1):149-60.
21 Pinheiro FP, Travassos da Rosa APA, Vasconcelos PFC. Arboviral zoonoses of Central and South America. Part G. Oropouche fever. In: Beran GW, editor. Handbook of zoonoses. 2nd ed. Boca Raton: CRC Press; 1994. p. 214-7.

22 Pinheiro FP, Travassos da Rosa APA, Vasconcelos PFC. An overview of Oropouche fever epidemics in Brazil and neighbour countries. In: Travassos da Rosa APA, Vasconcelos PFC, Travassos da Rosa JFS, editors. An overview of Arbovirology in Brazil and neighbouring countries. Belém: Instituto Evandro Chagas; 1998. p. 186-92.

23 Vasconcelos PFC. Yellow fever in Brazil: thoughts and hypotheses on the emergence in previously free areas. Rev Saude Publica. 2010 Dec;44(6):1144-9.

24 Vasconcelos PFC, Rosa APAT, Rodrigues SG, Rosa EST, Monteiro HAO, Cruz ACR, et al. Yellow fever in Pará State, Amazon region of Brazil, 1998-1999: entomologic and epidemiologic findings. Emerg Infect Dis. 2001 Jun;7(7):565-9.

25 Vasconcelos PFC, Rodrigues SG, Degallier N, Moraes MAP, Travassos da Rosa JFS, Travassos da Rosa ES, et al. An epidemic of sylvatic yellow fever in the southeast region of Maranhao State, Brazil, 1993-1994: epidemiologic and entomologic findings. Am J Trop Med Hyg. 1997 Aug;57(2): 132-7. 